\title{
Vulnerable Viewer Positions: Queer Feminist Activists Watching Paradise Hotel
}

Fanny Ambjörnsson and Ingeborg Svensson

Uncertainty strikes on the way up the stairwell. There are evidently two possible doors to choose from, both decorated with home-made door signs full of names. A scruffy head of hair peeks out from one of the doors. She nods cheerfully and points up: 'You're here to watch Paradise, right? It's one floor up.'

The collective, beyond the half-open door, smells like a collective usually does - a pleasant combination of boiled chickpeas, old incense and

Parts of this chapter were published earlier in Swedish (Bohlin and Gemzöe 2016).

F. Ambjörnsson ( $₫)$

Department of Ethnology, History of Religions and Gender Studies, Stockholm University, Stockholm, Sweden

e-mail: fanny.ambjornsson@gender.su.se

I. Svensson

Uppsala University, Uppsala, Sweden

e-mail: ingeborg.svensson@etnologi.uu.se

(C) The Author(s) 2020

A. M. Dancus et al. (eds.),

Vulnerability in Scandinavian Art and Culture, https://doi.org/10.1007/978-3-030-37382-5_10 
compost. It is soon to be joined by the smell of freshly popped popcorn, for it is Wednesday, the day devoted to joint viewing of Paradise Hotel.

In queer feminist activist circles, in Sweden and in other countries, there exists the phenomenon of gathering in groups to follow reality shows on TV. The purpose of this chapter is to investigate how this phenomenon can be understood. What emotions are involved and what meaning does it hold for the viewers? More generally, we are interested in how different forms of vulnerability are handled, mobilized and negotiated through the queer feminist viewers' meeting with the reality TV format Paradise Hotel.

The chapter starts out by contextualizing the study, describing the empirical data as well as the TV show to which the data relates, and at the same time positioning the lesbian, gay, bisexual, and transgender (LGBT) community in Sweden as a vulnerable and politically visible group. The subsequent section discusses theories of the reality genre, highlighting the relationship between the media and the audience, as well as discussing feminist re-readings of viewing positions as potentially transforming and empowering, rather than merely repressing. Tapping into theories of vulnerability-where the vulnerable is conceptualized as a relation and resource, rather than a subject position or victimhood-we use the activists' different affective investments in the programme to single out a queer feminist viewer position. Finally, the group watching of Paradise Hotel is analysed as a deeply vulnerable practice, where the queer feminist activists simultaneously negotiate marginalization, subordination and a longing for inclusion in mainstream society, as well as a potential middle-class advantage.

\section{The Viewers ANd Their Context}

The study is based on data consisting of interviews with a total of 11 people, as well as two participant observations during the actual viewing of the show. ${ }^{1}$ The interviewees live in a medium-sized city in southern Sweden and identify as lesbians/dykes or transgender. They are between 19 and 29 years old, and are all involved in the city's queer feminist activist circles. The group is differentiated by class but ethnically relatively homogenous (all of them grew up in Sweden). They were chosen because, as they have done for an extended period of time, they gather regularly to watch various reality programmes: this season the programme is Paradise Hotel. 
Group viewing of so-called reality programmes is not an unusual practice (Edin 2005). Surveys show that the viewership (in Sweden and in other countries) mainly consists of adolescents, young adults and women (Edin 2005; Hill 2005). The people we have interviewed are therefore not unusual. However, as political activists with particular involvement in queer feminist issues, we found it intriguing to investigate how they reason about watching programmes that are usually described as both heterosexist and commercial (Edwards 2004; Brown 2005; Skeggs and Wood 2012).

The group that we interviewed thus identifies as 'queer feminist activists', a term that has gained traction in a Swedish context ever since queer theory's establishment in Sweden in the 1990s (Ambjörnsson 2016). Don Kulick (2005) describes how the queer lines of reasoning in Sweden have mainly been combined with and filtered through a feminist analysis, something he believes has contributed to its strong position in a country with an influential women's movement (cf. Dahl 2011). In recent years, increased interplay between feminist, queer and anti-racist activism has taken place, resulting in presumably progressive public policies of gender, sexual equality and cultural diversity nationwide.

Although statistics show that LGBT people, women and ethnic minorities are marginalized and vulnerable in different ways, feminist, queer and 'diversity' perspectives have found their way into Swedish institutions (Koivunen et al. 2018). With this background in mind, it seems even more so interesting to investigate how different forms of vulnerability are handled and mobilized through the queer feminist TV viewers' encounters with the reality TV format of Paradise Hotel.

\section{Paradise Hotel and the Reality Genre}

Reality TV can be defined as a genre that claims to portray reality (Ganetz 2008). The programmes have 'ordinary' people in the main roles instead of actors, and they lack a script. Unlike the documentary, participants are put into reality programmes in staged situations. Reality TV also often contains elements of interaction with the audience-the viewers can participate in and influence who wins or loses. Anja Hirdman (2008) concludes that reality TV does not describe the relationship between an external reality and the representation of it, as is the case in the traditional documentary. Rather, the format is about the relationship between the medium and the audience. Yet another way to characterize the genre 
is that, rather than claiming to represent the truth, it is mainly about creating proximity and capturing the present. In line with this reasoning, Beverley Skeggs and Helen Wood (2012) claim that the communicative relationships that develop in the reality genre break down the division between the audience and programme participants, and thereby offer an extended social area where the critical distance between text and subject is reduced or-in some cases-is non-existent. Our article will mainly deal with the relationship between the medium and the audience, between the queer feminist viewers and the programme Paradise Hotel. But we also want to investigate how viewing the programme can be related to the informants' reality. It is in this meeting between fiction and reality that various forms of vulnerability are mobilized, managed and contested.

The programme we are dealing with in this chapter is Paradise Hotel which, at the time of the interviews, was broadcast on the Swedish commercial TV channel TV3. Paradise Hotel was conceived by an English production company and, since 2003 , has been produced in different versions in several countries worldwide. In Sweden, the number of viewers has consistently stayed at approximately 300,000 people, with a web audience as of the latest season (2019) amounting approximately to an additional 250,000 viewers. According to the statistics, two-thirds of these were women and the largest viewership group was between 15 and 24 years of age. ${ }^{2}$

The programme is about a group of young men and women who reside in a luxury hotel in paradisiacal climate. The camera's foci are scantily clad, muscly, silicone-boosted bodies: alcohol abounds and every night is a party. The participants' goal is to stay as long as possible at the hotel. This is done by pairing up with a person of the opposite sex. Anyone who ends up without a partner must check out of the hotel. The last couple left at the hotel wins 500,000 Swedish kronor, which they must decide whether to share with their partner... or not. In this way, until the very end, one runs the risk of being betrayed.

Paradise Hotel can be said to be part of the sub-genre of game shows. It is a game, although it contains no clearly defined elements of competition. Instead, the programme is centred around coalitions and rivalryto choose, to be chosen, or to be rejected. The viewer is mainly entertained by spats, sex, drunkenness, gossip and strong emotions. The rules of the game are constantly in flux and, in addition, the couples who manage to create a stable alliance are counteracted by novel contrivances by the producers. Uncertainty and unpredictability can be described as the 
core of the programme format (Madsen and Brinkman 2012). At the same time, the seriality is central-every new season is based on similar characters staying in the same environment, for several weeks in a row (Jerslev 2004). One can even go so far as to claim that the participants appear in accordance with a kind of soap opera repertoire, where similar lines, behaviours and characters return from season to season (Edin 2005, p. 26).

\section{Reality Shows, Agency and Vulnerability-A Theoretical Approach}

The reality genre has been criticized for intermediating neoliberal values, where surveillance and self-development are key ingredients in the construction of a self-controlling citizenship (Ouellette and Hay 2008). Furthermore, researchers have argued that the genre communicates and maintains limiting norms regarding whiteness, class, gender and sexuality (Ganetz 2008; Skeggs and Wood 2012). At the same time, since the 1980s, feminist research has discussed how women's consumption of romantic, mass-produced so-called 'junk culture' (wherein the reality genre can be said to be included) must also be understood as identity work and meaning making (Radway 1984; Ang 1985). Inspired by the feminist research tradition's interest in consumers, recent research has focused on the emotional response involved in the reception (Kavka 2008; Gorton 2009; Abrahamsson 2018). For example, Beverley Skeggs and Helen Wood (2012, p. 113) describe reality TV as a genre that is more about intervention than representation: 'a mode of television in which viewers' own lives are dramatically at stake in the mediation of everyday interpersonal drama'. The focus is therefore on the genre's characteristic immediacy and visually evident emotionality, which in itself is intended to enable openings beyond existing power dynamics.

This, of course, does not mean that power relations and potential vulnerabilities are rendered uninteresting. Rather, this 'turn' to embodiment and affect within feminist cultural studies has increased the interest in ways of understanding vulnerability as complex interrelations connected to power (Ahmed and Stacey 2001; Ahmed 2004; Koivunen 2010). Instead of understanding vulnerability as equivalent to passivity and victimhood, this strand of theorizing highlights both its connections to regulation and subjugation, and its power to bring together and mobilize political agency—what Koivunen et al. (2018) calls the 'double edge of 
vulnerability'. Especially within queer thinking, scholars have called for the need to reclaim and redefine vulnerability as a resource, as well as a common human condition (Shildrick 2002; Butler 2004). For instance, in her exploration of the role of trauma in lesbian public cultures, Ann Cvetkovich (2003) argues for the healing power of vulnerability in working through sexual stigma. Understanding sexuality and sex as areas that, by necessity, make the body vulnerable, Cvetkovich emphasizes how this vulnerability may, at the same time, offer a transformative space for political and personal agency—a reparative strategy (cf. Sedgwick 2003).

Drawing on this theorizing, regarding vulnerability less as a subject position but, rather, as a 'relation to a field of objects, forces, and passions that impinge on us or affect us in some way' (Butler 2016, p. 25), we want to investigate the relationship between the feminist queer activists and the reality format Paradise Hotel. How do the viewers react to participants who fight, humiliate, joke, threaten and perform gross actsmostly within the framework of what can be described as sexism, class contempt and homophobia? Inspired by Sara Ahmed's $(2004$, p. 8$)$ theorizing on relationality as different forms of emotional orientation, we are specifically interested in reactions of 'towardness' or 'awayness', through affective movements. We also relate these different affective investments to theoretical conversations on camp as a specifically queer way of handling vulnerability, both within the queer community (here: the queer feminist viewers) and in relation to the object of desire (here: the reality TV format Paradise Hotel).

Thus, by focusing on the workings of the medium in terms of affectwhich, in turn, compels the viewers to approach or distance themselves, to connect or to retreat-we want to discuss how different forms of vulnerability are mobilized, negotiated and managed through a queer feminist viewer position.

\section{Watching as Political World Making}

The people we interviewed have many friends who jointly watch reality TV shows one or several times a week. However, it was not at all a given that we would end up settling on Paradise Hotel specifically, for the group that we interviewed. Rather, the series is considered one of the more extreme in the reality genre. One of the viewers describes how they coincidentally ended up in front of the show and were repulsed. 
Maja: Like, I don't want to watch it on my own. I never thought I'd start watching this.

Eli: No, me neither!

Maja: And then I did it once and I just felt incredibly sick!

Fanny: What made you feel sick then?

Maja: Everything, I was about to say. How they behave, how they look. How they talk to each other and about each other and about everything. The hetero stress. Ugh. Yeah, and that the whole programme idea is so idiotic, that there's no logic to it, no point.

Livia: Yeah, those who get kicked out are allowed in again. I still don't get it.

Maja: It's just a big pile of fucking dog shit.

Why it is Paradise Hotel they all gather to watch, three days a week for almost three months, is something they themselves mull over. Much of it is about the community, of watching it together. During the interview, they all sit, concentrating intensely, on a large sofa in front of an old CRT TV. One of them has their feet in someone's lap, another fiddles with someone else's hair, and all the while a brownish-yellow cat prowls around their legs. When the programme introduction starts, they laugh aloud and sing along. Then total silence is demanded. The communication between the series' participants often consists of unclear lines, scarcely comprehensible without the utmost concentration. Emotional opinions are therefore delayed until advertising breaks, when viewers laugh hysterically, scream loudly, jump up and down on the sofa, applaud or gripe over participants' actions. As an outsider, one finds oneself quite lost-this is obviously a routine with which they are all well-acquainted, a common ritual. Several of them also describe how watching the show permits a routine in everyday life, even outside of watching time. They have created a common Facebook group around Paradise Hotel, they organize a wager on who will be the winner, and they have, as we will return to later, even tried to approach the programme participants in real life (IRL) on a night out.

As we can see, it is far from a passive, routine type of viewership they engage with. In their in-depth engagement with Paradise Hotel, our subjects could rather be described as fans (Duffett 2013). Unlike the classic definition of fandom, where worship and the cultural production that arises around this worship is centred on a specific object or person, these viewers focus on the community, rather than the object (Fiske 1992). 
None of them report wanting to watch Paradise Hotel on their own. They consume it is as a group, with a sense of community.

One explanation they give for why they watch reality shows together is that the programmes, and the interaction around them, becomes a sort of cohesive glue-something, along José Munoz' (1999) line of thinking, one could call 'world making' (cf. Ahmed 2006). Another reason is that watching, as they describe it, is perceived as a 'relaxation for the brain'. This is something reception studies of so-called junk culture have shown in various contexts (Skeggs and Wood 2012; Liliequist 2000). Evelina explains, giggling, that while others may go to the spa, she and her friends watch Paradise. 'Maybe it's a universal need to recharge to be able to face "hard reality".'

However, in order for the programmes to be perceived as relaxing, a different common denominator is required; namely, the political identification as queer feminist. As mentioned earlier, the viewers are all active in different queer feminist contexts. They choose to live in alternative types of relationships, live in a collective and in opposition to the gender binary norms, and they regard their political convictions as a central part of everyday life. This common outlook on the world becomes, so to speak, the prerequisite for being able to relax and create community around watching Paradise Hotel.

Rachel: I think you have to make yourself clear first. That's what I feel. But when I know I'm with someone I know shares my views, we have the whole analysis of how awful it is, then it would be unnecessary to make a statement about it. Then you just want to enjoy it-the sexism! (laughter) 'You have to indulge and enjoy it to its fullest!'

But it is not only a common political agenda; it is also about a common attitude to the political agenda. That is how Rachel describes what happened when she attempted to watch Paradise Hotel with her partner Jona.

Rachel: We watched an episode of Paradise Hotel together, but she couldn't stand it. And then we were going to watch another episode, and it was like she needed to comment on it all the time. And then said I: 'Enough, you can stop watching it and I'll watch on my own in peace!' (She laughs.) 
In a safe context where the political analysis and attitude to the programme is shared, the viewers can thus allow themselves, as Rachel jokingly puts it, to 'indulge and enjoy it to its fullest'. One simply does not have to be on guard when everyone already knows beforehand that the programme is politically reprehensible. In her analysis of debates about trigger warnings in feminist online forums, Katariina Kyrölä (2018) suggests the term 'vulnerable world making' (paraphrasing José Munoz' concept) to describe the enterprise of creating safer spaces for those living with trauma or societal stigma. Through trigger warnings (i.e. warnings about content that may be upsetting or offensive, or that could trigger post-traumatic stress), the activists try to avoid exposure to potentially injuring messages, thus performing a gesture of care for oneself and related others. The queer feminist viewers of Paradise Hotel also engage in a vulnerable world making, but instead of avoiding the possible triggers, they expose themselves to the worst kind of heterosexist 'junk'. Their potential vulnerability is thus managed, not by avoidance but by exposure-in a safe, queer feminist room.

\section{A Distant Reality}

A prerequisite for feeling safe when watching the programme is, thus, the shared attitude towards the programme. But the comfortable viewing is also about the fact that the programme's representation of reality feels distant. The forms of expression of gender and sexuality that the participants portray are admittedly both familiar and common in countless pieces of media. At the same time, they are perceived as so far removed that they do not intersect with the experiences of our interviewees' everyday lives. Instead, the programmes serve as an opportunity for our subjects to steal a glimpse of this 'hetero spectacle', to take part in something with which they are not quite familiar. Bella explains that it feels comforting to watch such crap TV and be able to conclude that she is 'so fucking far from all that'.

Bella: It's reality TV, but it's also a bit of fantasy. It feels a bit like that, because they are there in such strange conditions. The only thing they get is, like, alcohol. They have nothing else to do. It is a pretend world that's just completely absurd.

Eli: Also, about the fantasy world, like, the kind of people that participate are people I rarely meet.

Bella: Never! (States with emphasis.) 
Eli: And to look into it, into their thoughts and how they tick. Yeah, it really is quite crazy sometimes.

Bella: I really think that's the main purpose. That's what defines relaxing television for me. Like I can't watch anything that's too close to home, because it hurts all the way into my heart. But I can watch whatever sexist shit if it's a costume drama for example. If it's set in aristocratic countries in the 18th century... Then I'm like: 'go for it!' And the same with this. It's so fucking distant, so there's no way you could be provoked; on the contrary, you can just indulge in it and think to yourself: 'Who the hell would want to be heterosexual!?'

One aspect of the viewership that is perceived as pleasurable and safe is that the exhibited heterosexuality is perceived as distant and removed. In comparison to the shagging, fighting, partying and scantily clad participants in Paradise Hotel, the viewers feel somewhat more normal themselves. The feeling of normality, however, is based on the fact that Paradise Hotel cannot be correctly classified as exhibiting normative heterosexuality. Rather, it must be regarded as hyperbolic in the sense of the obscene, exaggerated and shameless (Madsen and Brinkman 2012). The participants' bodies are fit, covered with tattoos and piercings, clearly gone through plastic surgery and they exhibit a studied scantiness of clothing. They undress, bathe naked, make out, shag and sit on the toilet while unashamedly talking about how horny they are-all on camera. It is the illusion of a youthful, lustful and shameless heterosexuality that is put on display. Nevertheless, it is highlighted time and time again that the obscene, dissolute and non-respectable is also class coded-the participants do not embody a bourgeois intellectual ideal with control and moderation as main markers (cf. Skeggs 1997). Several of them talk of Paradise Hotel as their opportunity to 'become something'-at the same time as producers repeatedly edit sequences that show their lack of general education. The viewers' sense of normality is thus based on a feeling of distance, not only to the exhibited heterosexuality, but also to the subordination of a class position. At the same time, the distancing includes a fascination for precisely that which is perceived as unbridled and tasteless. The characters in the programme play the role of living out the life that, for different reasons, one has never gained access to, not been able to live, or opted to not choose. 


\section{Approaching 'The Ordinary'}

If one of the conditions for being able to watch the programme is its perceived distance from everyday life, there is, in the same movement, a desire for intimacy with other viewers. By watching a reality TV series for young people, they also have something in common with all other young viewers between 15 and 30 years. Several of them describe this as a longing to share common cultural expressions with others, more 'ordinary people'. Rachel describes how an important aspect of their viewing of reality TV is precisely the 'mainstream feeling'; keeping up with the discussions at work and recognizing the names that appear on the evening paper posters. Maja also describes how watching it makes her feel closer to 'the mainstream'. When she worked with young people a few years ago, she started reading blogs written by participants in Paradise Hotel, to keep up with the collective conversation. She points out that watching Paradise Hotel gives insights into other worlds and, at the same time, opportunities to learn new things.

Maja: So, I'm aware of the concept of girls making out with each other to make the guys horny, but there's been a lot of guys making out with other guys. And then I've been a little like: 'what now?' 'No, am I a little ...?' Like being completely behind with the thing that apparently you're not supposed to have unerect nipples, I got to learn...

Livia: What?

Bella: 'Sauna tits', like Aina said!

Maja: You can't have sauna tits! And then I was like: 'What, isn't it a bit shameful to have stiff nipples?' And they were like: 'No, that was so ten years ago...'

(Everyone laughs.)

Maja: You're supposed have stiff nipples and guys make out with guys at parties. New stuff!

Approaching 'the alien' thus includes a multitude of aspects - they learn new things, become more 'mainstream competent' and feel involved in a larger community. Here, also, we are dealing with an ongoing construction of normality. By consuming the same TV programmes as their workmates, learning the names of the participants and revelling in soap opera gossip, they feel more involved in a community from which they otherwise partly distance themselves, in which they partly do not always feel included. 
The willingness to approach can thus be regarded as a processing of their sexual exclusion. At the same time, and in the same movement, the distance to the mainstream and 'the popular' is emphasized. Beverley Skeggs and Helen Wood (2012) claim that, for the middle class, a distinctive motivation to consume mass culture is self-development; one learns something about an imagined other world, a learning that in the future can constitute a cultural capital. Through this line of reasoning, we can conclude that the viewers' approachment and learning constitute a managing of a vulnerable sexuality as well as a creation of middle classthat their attempts at feeling normal are based on a subordination of an assumed vulnerable class position.

\section{When Reality TV Becomes Reality-From Lesbian Heaven to Paradise Hotel}

So far, we have described how the interviewees relate to the series as remote and thereby partly manageable. By alienating it, they can also approach it in different ways: revel in it, enjoy it, learn from it and fetishize it. The movement is thus an approach that is made possible by alienation. However, there are sequences in the conversation when their own and the series' realities meet-and the boundaries partly collapse.

Eli: We had found out that Samir, a fun guy, I think, and Jeppe, the abso-

lute worst, would be coming to a club exactly fifty meters away from here.

Livia: Where we also usually go to another club called Lesbian Heaven.

(They laugh.) If I hadn't been there, at Lesbian Heaven, I don't know if I'd thought it was as fun.

Maja: Like, the same place, yeah.

Eli: It was free and we thought: 'Why not? Let's go there!'

Livia: So we went there, half past eleven, like after bedtime.

(The others giggle.)

Eli: And had dressed up in shirts... Lesbian shirts...

Fanny: Ahh, you had dressed up as lesbians?

(Everyone laughs.)

Eli: And so we go past the guards, who gave us a strange look. Or maybe they didn't.

Livia: Yeah, it's just so crazy that we went there! And then we came into this completely empty room with three girls sitting and drinking drinks 
and an empty dance floor. And so we sat down there, very uncomfortably in a small sofa group.

Eli: I was so ashamed! I just felt, 'No, no, no, no, no, no!' I felt that my wall was being razed or my distance to them.

Livia: But they weren't there, they were going to be coming...

Eli: It was cancelled, apparently. So we sat there waiting...

Fanny: In your lumberjack shirts?

(Laughs.)

Eli: For twenty minutes. Then I went out and asked the bartender: 'Where is Samir and Jeppe?' (One of them erupts in bubbling laughter.)

Eli: 'Where are they?' (In a demanding tone.)

Eli: And then she said, 'No, I'm terribly sorry, but they've cancelled.' (In a soft/feminine service voice.)

(The others giggle.)

Eli: It was also during Pride Week (Pride was the theme of one week's episode of the programme, author's comment) and one of the participants had come out as bisexual and then Samir had said: 'Really fucking brave of you to have done that on TV. You are my role model.' So we had kind of said we were gonna come out of the closet for him so that we would become his role models.

(Everyone giggles.)

Eli: Force our way through the crowd and say, 'We're coming out!'

Eli: And get his attention somehow! But then they didn't show up...

(One of them sighs a big sigh, contemplating the memory.)

Fanny: If there had been more than three other people there, would you then have thought that you stood out from the others?

Livia: We had done that, because we were sitting there in our corner and looking completely out of place.

Eli: I think we already thought we stood out. I think I had a picture in my head of the people that would come there and that they were like those three girls in short dresses sitting there. So I already felt pretty fucking stupid.

Livia: Yes, but that's what was so strange. 'Cause it was like then when we were sitting there... We went there and then it felt like I was being quite ironic and kind of like: 'Ohhh, I'll put on my lumberjack sweater!' And when you come in there I'm gonna greet Samir in a different way than these other fans who are more mainstream. But then, when we sat there, it was like I realized I was no different. Or, like, we're just as ridiculous as them.

Maja: To sit there at the pub and suddenly find it a bit embarrassing, it's also because the distance creates some kind of feeling that we're a little 
bit better than them. A little better than the fans who went there unironically, who haven't dressed up or have made it a thing of going there.

In this sequence reality makes an intrusion-or is it perhaps rather that they, inspired by watching Paradise Hotel, allow the different realities to meet. Suddenly they are forced to relate not only to a media text, in a safe social environment and with the TV screen as a filter, but also to the actual people in the TV series (who admittedly did not show up). In the same way, the other viewers become a reality to which to relate. Who are they really in relation to other viewers and fans? And what would they be in relation to the real Jeppe and Samir?

By letting go of the boundaries between fiction and their own reality, they jeopardize the distance on which we have hitherto concluded their viewership to be based. The visit to the pub is thus a precarious endeavour. How is it that they dare to leave their safe space at all?

First, we can note that the specific place plays a central role. The intended meeting takes place at a location near their home, a place they have previously visited and that is partly subculturally coded, in that it previously housed the ambulatory lesbian nightclub Lesbian Heaven.

The time of the visit is also vitally important. Paradise Hotel has just had what is called Pride Week, when the participants are encouraged to play with gender transgressions and homosexual urges. This week, two new participants have joined the programme, a bisexual girl and a transvestite. When Samir explicitly expresses his admiration for the bisexual Linnea's courage to come out on TV, it is seen by the informants as if they, too, were addressed. As they somewhat jokingly express, they, too, want to come out in front of Samir. They want to show who they are, get Samir's recognition and perhaps even become his role models. Based on these premises, they get the idea of joining the game. They dress in identical lesbian coded lumberjack shirts-and act hyperbolically, similar to way the participants in Paradise Hotel do (given the already determined soap opera repertoire).

However, this closing of distance also makes them vulnerable. As Lotten Gustafsson (2002) notes, the vulnerability in the act of playing is linked to the fact that the participant is required to perceive and interpret the meta-communication of play signals accurately. In this case, it is unclear whether they are even recognizable as participants in the game. And Samir never shows up. Instead, they sit uncomfortably waiting, 'long 
after bedtime', feeling increasingly out of place, together with three other girls, who are probably also there to 'play'.

In their engagement with Paradise Hotel, they have obviously imagined themselves as different than other viewers. This hierarchy becomes clear when they suddenly sit side by side in the same room, waiting for Jeppe and Samir. In this act of closing the distance, they no longer perceive themselves as superiors. Neither are they equals. Rather, it is they themselves who, in their own eyes, appear to be incomprehensible, strange and wrong. Moreover, the former feeling of superiority is also felt as neither politically nor ethically desirable-in the actual situation. The distancing, as we have previously discussed in terms of approachment and superordination, is simply not as possible when reality encroaches. They cannot enjoy this form of mass culture in a comfortable way outside of their safe space. They see their elitism, do not stand for it, feel their vulnerability and go home with an unfulfilled goal.

\section{Too Much of A Good Thing}

When the fantasy world suddenly comes to resemble reality, the viewers are put in more or less ethical dilemmas. Another such ethical dilemma seems to arise when the content of the programme is about their own identifications, when the fiction is simply no longer perceived as distant, but as approaching their own reality.

Fanny: So Pride Week, didn't it feel quite comfortable in the end?

Evelina: No, there was so much transphobia that it was hard to watch. Like it was meant to make you laugh. It just felt like: 'Ugh!!' (In a tired, distancing tone.) It went something like this: a guy came who was in drag, a drag queen, and then all the guys went on a date with him. And all guys were like: 'Ew, a dude in girl clothes!' But in the end, they still thought it was fun. And then he had a competition where those guys were supposed to get into full drag. And it was just like everyone laughed at looking funny in their dresses.

Bella: Mmm... The idea was that they were supposed to let go, be generous and open and give people a laugh.

Evelina: Then that makes me think that what was difficult about it was that maybe it came a step closer, so to say...

In the conversation above, we see how the viewers find it harder to digest the representation of a reality they themselves are familiar with. 
At the same time as Pride Week, which makes some of them feel emboldened enough to join the game and seek out the programme participants IRL, they feel that non-heterosexuality is misrepresented. They apparently become stricter-and feel more uncomfortable-when Paradise Hotel delves in LGBT matters and Pride; that is, their own reality.

Another form of distancing arises when the content of the programme involves a distant hyperbolic fiction that they can revel in and be horrified by-when they are reminded that violent expressions and oppressive rhetoric also exists outside the programmes.

Fanny: You say it's comfortable because it's so far away and a little uncomfortable when it comes too close?

Evelina: Yes, last week was so hard!

Eli: Exactly, it was unpleasant. You're just like: 'People like that walk around on the streets! Ew! Those are evil people!'

(The others agree.)

Maja: They sang like some kind of rape song. And this thing about begging for sex.

Malle: And Jeppe, or somebody, had jerked off to a picture of Emily. And Jeppe has so much fucking power and is a real pig and everyone does what he says. It's uncomfortable.

Maja: Yeah, he sits there and says in the interview that he's gonna piss on everyone...

Livia: Yeah, but he did say sometime, like, that he's not there to be liked by the girls. No, he wants to walk down Götgatan receiving high fives from guys who respected him for shagging lots of chicks and being boss.

When the programmes become difficult to regard simply as fiction, when the boundary between realities break down and reality becomes too intrusive, it obviously becomes harder to swallow. Above all, this applies when the homophobic and sexist elements become too obvious, when the guys behave like pigs towards the girls, or when the participants act homophobic and transphobic. Then the viewers throw their support behind the vulnerable-in solidarity with girls, gay men and transgender people, they jump up and down on the sofa in anger over the boys' mean actions and rude sex jokes. They pep talk the female participants to stand up for themselves when they occasionally try to exact revenge, and laugh with schadenfreude when one of them manages to manipulate a guy to get sent home. When the producers let the girls have a whole day for themselves alone at the hotel-and they gigglingly teach each other how to shove 
a ball up their vaginas and then trick one of the guys to put it in his mouth-it is talked of as one of the best episodes in the series. When one of the girls, in front of the camera, describes the 'girls' day' as the nicest and best of the entire stay, everyone applauds.

In many ways, these emotional responses to the programmes are similar to a heterosexual sex war, where there is always the risk that the 'wrong' side wins. This is also what happens when Jeppe, a person they all strongly dislike and who they perceive as a heterosexist male chauvinist, suddenly comes back into the programme with great odds of winning. Earlier in the series he had been voted out - they had all cheered and felt happy all week. Now he has returned for no obvious reason. They describe themselves as very bummed out. If Jeppe wins, that means that he will walk out - out into real life-with half a million kronor in prize money. And suddenly the fiction is no longer a distant fantasy, but takes place in their own environment, on both Götgatan and in their own neighbourhood. A person that previously actively participated in the communal viewing left when they found it 'too disgusting'. And at the prospect of the last few episodes, several of the participants feel uncomfortable.

Eli: It's like everyone agrees with what he says. That he's constantly saying that he's so strong and everyone believes him.

Bella: Yeah, but that's because people are afraid of him. Because he threatens to beat them up.

Livia: Yeah, well in that case it's pretty fucking bad.

Bella: That's why it's so disgusting that he's got a role like that, that you can feel is also real in some way.

Eli: When he came back it was like it wasn't just us who were shaking with fear. It was all of them.

Livia: But, like, if he wins, I don't think I'm gonna want to watch this anymore.

$E l i$ : Yeah, it's over then (some teasing laughter.)

Livia: Come on, I mean next season.

\section{Managing Vulnerabilities-A Queer Feminist Viewer Position}

The reality genre's game shows do not make for high culture capital. Neither is one assumed to learn anything, as is the case in a large share of the reality programmes: how to raise children, lose weight, fixing one's finances and so on. Instead, Paradise Hotel is a long-lasting, rather anarchic booze party with half-naked bodies, a great deal of alcohol and plenty 
of talk about sex. Neither does following Paradise Hotel generate any activist or feminist brownie points.

So, how then can one make sense of the feminist queer activists' consumption of Paradise Hotel? With a focus on affect-the emotional response and direction the programmes generate-as a starting point, we have suggested a number of answers to that question. By gathering together, several nights a week, around the TV, they create a common safe space in which they can relax, enjoy themselves and let go. By estranging themselves from the programme, they establish themselves as more normal. At the same time, the viewing habit also includes an approachment - to popular culture and the 'mainstream world' outside their own activist bubble. A possible answer to what the viewers do with the programme is that they negotiate and experiment with different forms of vulnerability: they handle their own sexual exclusion, make themselves more normal and, in the same breath, distance themselves from a class coded sexuality. Another answer is that, by watching Paradise Hotel, they make themselves queer feminists. In this final discussion, we would like to spend some time on how this queer feminist viewer position could be described.

Paradise Hotel can be considered a text that viewers approach in a specific way. It is, as we have shown earlier, not only the political agenda that must be shared for the viewing to feel safe and entertaining; it also requires a special attitude to the programme-what we choose to call a 'queer gaze'. Studies on the consumption of so-called junk culture often emphasize how contemporary consumers take on, what one usually calls, an ironic viewing position (Jameson 1984; Liliequist 2000). By placing the product inside quotation marks and approaching its message from an ironic viewing stance, it is possible for viewers, not least those from the middle class, to consume cultural expressions that are otherwise usually described as class marked 'junk'. The queer gaze is reminiscent of an ironic viewing stance-but only partially. In the following section, we would therefore like to examine possible differences when using the concept of camp.

Camp can be characterized as a style, an aesthetic, or a way of thinking that takes hold of hyperbole and artificiality and celebrates the unnatural, failed and fallen (see, for example, Sontag 1966; Dollimore 1991; Cleto 1999). In addition, camp also requires seriousness. Rather than an ironic, detached gaze, the attitude is based on emotional proximity that can aptly be described as a self-parodying dedication. 
Camp often stands in relation to mass-produced and commercial pop culture. The person that 'camps', however, is outside the majority culture, historically in a predominantly male homosexual culture (Cleto 1999). In an article about schlager music, emotions and Swedish homosexual culture, Tiina Rosenberg (2005) describes schlager music consumption among gays as camp, and mainly a male, homosexual resistance strategy. 'Camp', writes Rosenberg $(2005$, p. 354), 'is a way of relating to the world that has been particularly important for homosexuals as a refuge from heteronormativity.' In this sense, it can be understood as, in Eve Kosofsky Sedgwicks (2003, pp. 123ff.) words, a reparative strategy-a specifically queer way of handling vulnerability.

So, what does camp have to do with Paradise Hotel? It is to be regarded as a form of excess and exaggeration of a tabooed and culturally shunned part of reality, something often cherished among camp practitioners (Sontag 1966). This is also how one of the viewers describes the programme in our conversation, as 'big pile of fucking dog shit'. Seen from this point of view, Paradise Hotel makes for a relaxing time on the sofa, where the queer feminist viewers, along with other like-minded people, in a contradictory and fascinated fashion, can engage with heterosexual stereotypes and revel in exaggerated ideals. The point here is that they are remarkably un-ironic; the viewing can more aptly be characterized by intimacy, empathy and great emotional engagement. Thus, in safe spaces, we see how they let go, engage and, in a way, solidarize with the rejected 'junk'.

Paradise Hotel, however, is not to be considered as any popular cultural product. Through its aesthetics and programme concept, it is criticized for being extra 'trashy' (cf. Hagström 2014; af Kleen 2014; Gustavsson 2014; Arif 2015). As viewers, we are invited to watch shamelessly and be entertained by the participants' unabashed behaviour-they get drunk, argue, cry and have sex unashamedly, with open curtains. In this sense, the programme can be said to be an exercise in shamelessness (Madsen and Brinkman 2012). And within here lies a deeper explanation of the programme's attractiveness to the queer feminist viewers. In their identification with queer, in its broad sense of that which is excluded, there exists, so to speak, queer brownie points to be collected. Queer is a movement in the direction of the despicable, rejected and, above all, shameless-not aiming at a rectification and recognition but, rather, to embrace the fallen as well as the 'failure' (Halberstam 2011). In this way, the informants' involvement can be expected to give rise to a deeper identification 
with and care for the vulnerable and despised. On some level, the programme participants' constant fear of being socially and sexually excluded from the programme, handled through shameless and sexually provocative behaviour, is culturally and emotionally recognizable by the queer feminist viewers. Paradise Hotel is thus possible to like-not despite, but because of its terrible shamelessness. In addition, we see how the viewers, through their consumption, overcome themselves-in the sense that not everything has to be completely 'correct' all the time. In their view of themselves as norm-critical feminists and anti-capitalists, they are simply not straight-rather, they are shameless and queer. Through a camp approach to the programme, they collect queer points, so to speak, and reinforce their view of themselves as queer feminists, embracing the vulnerable.

The camp attitude could thus distinguish a generally ironic late modern viewing stance from the queer feminist viewers' attitude more reminiscent of the gay men's camp viewing of schlager music (cf. Rosenberg 2005). However, in a similar fashion to gay men's consumption of schlager music, the approach to Paradise Hotel also contains an element of subordination. In the moment that I make something camp (that is, make it lovable garbage'), I have also made myself superior. Through its celebration of a stereotyped femininity, gay culture's camping of femininity has often been criticized for reproducing the binary gender system and, thus, female subordination (Robertson 1996, pp. 3f.). In a similar fashion, we see how the queer feminists' delight in the class coded hetero spectacle enhances a class division. The camp attitude thus tends to participate in structures that perpetuate existing hierarchies.

In this way, the queer feminist camp viewing of Paradise Hotel resembles gay men's consumption of schlager music. At the same time, it is a much more complicated enterprise. For, in the camp consumption of Paradise Hotel, it is not just a case of the subordinate and vulnerable predominantly woman and gay man, exaggerated and exposed, but also the superordinate oppressive man. And here, we see how viewers end up in a dilemma. They solidarize with and idealize participating women, gays and transgender people, but devote the greatest energy to hating the chauvinistic heterosexual men. When the person they all perceive as the worst offender ends up winning the whole thing, they lose the drive that previously compelled them to watch. At this point, it is no longer possible for them to celebrate and be dedicated to the shameless and fallen; rather, it seems reasonable to stop watching and begin to question the whole 
enterprise. At this point, it seems, both their will and ability to camp the programme ceases.

The camping thus appears to be a more vulnerable project for the queer feminist activists, precisely because of their identification and/or solidarity with the female position. Camp also becomes more difficult to carry out when they leave their safe space and enter the real world; when they, so to speak, camp themselves by exaggerating and giving into the lesbian stereotype. The endeavour of staging themselves as stereotypical lesbians, in lumberjack shirts-to offer themselves up as participants in a joint game-fails, not only because the programme participants do not show up, but mainly because the lesbian stereotype is not sufficiently culturally recognizable. Unlike the gay man that 'sissies around' or 'transes about' (like the transgender person in the programme), the lesbian position is simply not equally viable. It is not, at this time in history, as culturally recognized and has no specific role to play. Thus, camp, from this perspective, comes to be regarded as a more difficult undertaking for a person holding a female identification/position.

\section{CONCLUSION}

To sum up, we can conclude that the queer feminist viewer position that we have investigated is centred on the intricate ways of handling and experimenting with different forms of vulnerability-their own, and that of the programme participants and the other viewers.

Through emotional reactions of 'towardness' and 'awayness', the queer feminist viewers handle their sexual exclusion, make themselves more normal at the same time as they distance themselves from a class coded sexuality. However, the viewing differs from an ironic viewing stance by not being ironically detached. Rather, it builds on the simultaneous approaching and distancing of the vulnerable and fallen, mirrored by the programme participants' ongoing struggles to handle social and sexual exclusion through strategies of shamelessness. Watching Paradise Hotel thereby becomes a possible way of overcoming and managing sexual exclusion. Thus, unlike the closed feminist forums trying to avoid possible triggers and potential vulnerability through trigger warnings, the viewers deliberately expose themselves to sexist, homophobic 'trash' by using a camp attitude. However, as a reparative strategy, it is a deeply vulnerable enterprise. When the abuse becomes too obvious and the men in the programme behave too reprehensibly, it is no longer possible to camp. 
Neither does camp work when they put their own identities at stake and perceive themselves as unrecognizable. There is nothing left to do other than to turn off the TV—at least, as Livia notes, until the next season.

\section{Notes}

1. The material, which was collected in 2015 , consists of two group interviews, one with three interviewees and one with seven, lasting about three hours each. An additional one-hour interview was conducted with one interviewee. Two participant observations were performed during the actual interviews. All material has been transcribed verbatim.

2. The information is derived from MMS (Mediemätningar i Skandinavien), www.hottoptv.mms.se. Accessed 6 June 2019.

\section{REFERENCES}

Abrahamsson, E. (2018). Enahanda läsning: En queerteoretisk tolkning av romancegenren. Stockholm: Makadam.

af Kleen, B. (2014, September 19). Paradise Hotel är motsatsen till frigörelse. Dagens Nyheter.

Ahmed, S. (2004). The Cultural Politics of Emotion. Edinburgh: Edinburgh University Press.

Ahmed, S. (2006). Queer Phenomenology: Orientations, Objects, Others. Durham: Duke University Press.

Ahmed, S., \& Stacey, J. (2001). Introduction: Dermographies. In S. Ahmed \& J. Stacey (Eds.), Thinking Through the Skin. London: Routledge.

Ambjörnsson, F. (2016). Vad är queer? Stockholm: Natur \& Kultur.

Ang, I. (1985). Watching Dallas: Soap Opera and the Melodramatic Imagination. London: Methuen.

Arif, A. (2015, January 16). Könsroller in absurdum. Feministiskt perspektiv.

Bohlin, A., \& Gemzöe, L. (Eds.). (2016). Fiktion och verklighet: Mångvetenskapliga möten. Stockholm: Makadam.

Brown, L. S. (2005). Outwit, outcast, out-flirt? The women of reality TV. In E. Cole \& J. H. Daniel (Eds.), Featuring Females. Feminist Analyses of Media. Washington, DC: American Psychological Association.

Butler, J. (2004). Precarious Life: The Powers of Mourning and Violence. London: Verso.

Butler, J. (2016). Rethinking vulnerability and resistance. In J. Butler, Z. Gambetti, \& L. Subsay (Eds.), Vulnerability in Resistance. Durham: Duke University Press. 
Cleto, F. (Ed.). (1999). Camp: Queer Aesthetics and the Performing Subject-A Reader. Ann Arbor: University of Michigan Press.

Cvetkovich, A. (2003). An Archive of Feelings: Trauma, Sexuality, and Lesbian Public Cultures. Durham: Duke University Press.

Dahl, U. (2011). Queer in the Nordic region: Telling queer (feminist) stories. In L. Downing \& R. Gillett (Eds.), Queer in Europe: Contemporary Case Studies. Farnham: Ashgate.

Dollimore, J. (1991). Sexual Dissidence: Augustine to Wilde, Freud to Foucault. Oxford: Clarendon Press.

Duffett, M. (2013). Understanding Fandom: An Introduction to the Study of Media Fan Culture. London: Bloomsbury.

Edin, A. (2005). Verklig underhållning: Dokusåpor, publik, kritik. Stockholm: Institutet för mediestudier.

Fiske, J. (1992). The cultural production of fandom. In L. A. Lewis (Ed.), The Adoring Audience: Fan Culture and Popular Media. London: Psychology Press.

Ganetz, H. (2008). Talangfabriken: Iscensättningar av genus och sexualitet $i$ svensk talang-reality. Centrum för genusvetenskap: Uppsala Universitet.

Gorton, K. (2009). Media Audiences: Television, Meaning and Emotion. Edinburgh: Edinburgh University Press.

Gustafsson, L. (2002). Den förtrollade zonen: Lekar med tid, rum och identitet under Medeltidsveckan på Gotland (Doctoral dissertation). Stockholm: Nya Doxa.

Gustavsson, M. (2014, September 9). De har inga mobiler att försvara sig med i Paradise Hotel. Dagens Nybeter.

Hagström, J. (2014, August 23). Rent människoförakt i Paradise Hotel. Göteborgs-Posten.

Halberstam, J. (2011). The Queer Art of Failure. Duke: Duke University Press.

Hill, A. (2005). Reality TV: Audiences and Popular Factual Television. London: Routledge.

Hirdman, A. (2008). Televiserad verklighet och emotionernas betydelse. In A. Edin \& P. Vesterlund (Eds.), Svensk television: En mediehistoria. Stockholm: Statens ljud-och bildarkiv.

Jameson, F. (1984). Postmodernism, or, the cultural logic of late capitalism. New Left Review, 146, 53-92.

Jerslev, A. (2004). Vi ses på TV: Medier og intimitet. Köbenhavn: Gyllendal.

Kavka, M. (2008). Reality Television, Affect and Intimacy: Reality Matters. Hampshire: Palgrave Macmillan.

Koivunen, A. (2010). An affective turn? Reimagining the subject of feminist theory. In A. Koivunen \& S. Paasonen (Eds.), Disturbing Differences: Working with Affect in Feminist Readings. London: Routledge. 
Koivunen, A., Kyrölä, K., \& Ryberg, I. (2018). Vulnerability as a political language. In A. Koivunen, K. Kyrölä, \& I. Ryberg (Eds.), The Power of Vulnerability: Mobilising Affect in Feminist, Queer and Anti-racist Media Cultures. Manchester: Manchester University Press.

Kulick, D. (2005). Inledning. In D. Kulick (Ed.), Queersverige. Stockholm: Natur \& Kultur.

Kyrölä, K. (2018). Negotiating vulnerability in the trigger warning debates. In A. Koivunen, K. Kyrölä, \& I. Ryberg (Eds.), The Power of Vulnerability: Mobilising Affect in Feminist, Queer and Anti-racist Media Cultures. Manchester: Manchester University Press.

Liliequist, M. (2000). Våp, bitchor och moderliga män: Kvinnligt och manligt $i$ såpoperans värld. Umeå: Boréa.

Madsen, O. J., \& Brinkman, S. (2012). Lost in paradise: Paradise Hotel and the showcase of shamelessness. Cultural Studies-Critical Methodologies, 12(5), 459-467.

Munoz, J. (1999). Disidentifications: Queers of Color and the Performance of Politics. Minneapolis: University of Minnesota Press.

Ouellette, L., \& Hay, J. (2008). Better Living Through Reality TV. Oxford: Blackwell.

Radway, J. A. (1984). Reading the Romance: Women, Patriarchy, and Popular Literature. Chapel Hill: University of North Carolina.

Robertson, P. (1996). Guilty Pleasures: Feminist Camp from Mae West to Madonna. Durham: Duke University Press.

Rosenberg, T. (2005). Schlager, känslor och svensk homokultur. In D. Kulick (Ed.), Queersverige. Stockholm: Natur \& Kultur.

Sedgwick, E. K. (2003). Paranoid reading and reparative reading, or, you're so paranoid, you probably think this essay is about you. In E. K. Sedwick (Ed.), Touching Feeling: Affect, Pedagogy, Performativity. Durham: Duke University Press.

Shildrick, M. (2002). Embodying the Monster: Encounters with the Vulnerable Self. London: Sage.

Skeggs, B. (1997). Formations of Class and Gender: Becoming Respectable. London: Sage.

Skeggs, B., \& Wood, H. (2012). Reacting to Reality Television: Performance, Audience and Value. London: Routledge.

Sontag, S. (1966). Against Interpretation, and Other Essays. New York: Dell. 
Open Access This chapter is licensed under the terms of the Creative Commons Attribution 4.0 International License (http://creativecommons.org/licenses/ by $/ 4.0 /$ ), which permits use, sharing, adaptation, distribution and reproduction in any medium or format, as long as you give appropriate credit to the original author(s) and the source, provide a link to the Creative Commons license and indicate if changes were made.

The images or other third party material in this chapter are included in the chapter's Creative Commons license, unless indicated otherwise in a credit line to the material. If material is not included in the chapter's Creative Commons license and your intended use is not permitted by statutory regulation or exceeds the permitted use, you will need to obtain permission directly from the copyright holder.

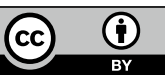

